\title{
КУЛЬТУРА ПЕДАГОГІЧНОГО СПІЛКУВАННЯ В КОНТЕКСТІ КОМПЕТЕНТНІСНОЇ ПАРАДИГМИ ПРОФЕСІЙНО-КОМУНІКАТИВНОЇ ПІДГОТОВКИ ВЧИТЕЛІВ ПОЧАТКОВИХ КЛАСІВ
}

Онищенко І. В. Культура педагогічного спілкування в контексті компетентнісної парадигми професійно-комунікативної підготовки вчителів початкових класів.

У статті описано технологію формування культури педагогічного спілкування майбутніх учителів початкових класів; визначено умови, шляхи, особливості формування професійної комунікативної компетентності майбутніх учителів початкової школи.

Ключові слова: спілкування, педагогічне спілкування, культура педагогічного спілкування, комунікативна компетентність, мовлення.

Онищенко И. В. Культура педагогического общения в контексте компетентностной парадигмы профессионально-коммуникативной подготовки учителей начальных классов.

В статье описывается технология формирования культуры педагогического общения будущих учителей начальных классов; определяются условия, пути, особенности формирования профессиональной коммуникативной компетентности будущих учителей начальной школы.

Ключевые слова: общение, педагогическое общение, культура педагогического общения, коммуникативная компетентность, речь.

Onishchenko I. V. Culture of pedagogical intercourse within the context paradigm professional competence and communication training primary school teachers.

The article describes the technology of a culture of pedagogical communication of primary school teachers; defined conditions, ways, especially the formation of professional communicative competence of primary school teachers.

Key words: communication, pedagogical communication, culture, pedagogical communication, communicative competence, language.

Переорієнтація сучасної вищої педагогічної освіти на європейські стандарти передбачає, насамперед, підготовку компетентного фахівця, який усвідомлює свою соціальну відповідальність, уміє визначати нові педагогічні цілі і успішно їх досягати, є суб'єктом особистісного i професійного зростання, ключовою фігурою у формуванні життєвої компетентності учнів. Компетентнісно-орієнтована освіта - складна, 
багатоаспектна проблема, яка на сьогоднішній день не $є$ достатньо дослідженою.

У своїй професійній діяльності сучасний учитель зіштовхується 3 необхідністю не лише сформувати знання, але й навчити способів одержання цих знань, формувати навчальну діяльність школярів, будувати освіту як систему, що створює умови для самопроектування і формування багатомірної свідомості, здатності самовизначатися, розвивати в школярів техніки розуміння, мислення, дії, рефлексії.

Гуманізація системи освіти, що характеризує сучасний етап іiі розвитку, висуває високі вимоги до загальної та професійної підготовки педагогічних кадрів, прояву їх творчої індивідуальності. Педагогічна діяльність є складною та багатокомпонентною. Н. Кузьміна виокремлює такі компоненти педагогічної діяльності: змістовий, методичний i соціально-психологічний [6, с. 21]. Вони утворюють внутрішню структуру педагогічного процесу. Єдність і взаємозв'язок цих трьох компонентів дозволяють реалізувати повною мірою завдання педагогічної системи. Головним $\epsilon$ соціально-психологічний компонент, тобто педагогічне спілкування, що забезпечує реалізацію двох інших.

Сфера формування особистості - це, насамперед, активна міжособистісна взаємодія, комунікація, оскільки саме через педагогічне спілкування здійснюється персоналізація вчителя в своїх учнях, прищеплення їм загальнолюдських та національних цінностей, набуття ними соціального досвіду, формування їх як особистостей. У спілкуванні складається важлива система виховних взаємин, сприятливої ефективності виховання й навчання. У педагогічній діяльності спілкування набуває функціонального i професійно значимого характеру. Воно $є$ в ній як інструмент впливу: і звичайні умови, і функції спілкування одержують тут додаткове «навантаження», тому що 3 аспектів загальнолюдських переростають у компоненти професійно творчі.

Тому особливої актуальності та значущості набуває проблема формування професійно-комунікативної компетентності вчителя.

Аналіз останніх досліджень і публікацій. У психолого-педагогічний літературі професійно-комунікативна компетентність визначається як «уміння встановлювати і підтримувати необхідні контакти 3 іншими людьми» (Ю. Жуков, С. Козак, С. Макаренко, Л. Петровська, Ю. Рись, В. Степанов, В. Ступницький та ін.); «володіння сукупністю комунікативних умінь (Є.Головаха, Т. Ладиженська, Є. Мелібруда, Н. Паніна, Р. Парошина, М. Станкін та ін.); «знання норм і правил спілкування» (А. Козлов, Т. Іванова та ін.). Вирішення проблеми формування професійно-комунікативної компетентності майбутніх вчителів початкових класів у системі вищої педагогічної освіти вимагає розробки теоретико-методологічної стратегії в умовах нової педагогічної парадигми, яка грунтується на ідеях модернізації, гуманізації гуманітаризації освіти. 
Теоретичні та експериментальні дослідження формування культури педагогічного спілкування проводилися вітчизняними й зарубіжними вченими в таких аспектах: структура, функції та види спілкування (Л. Долинська, Л. Зінченко, В. Кан-Калик, А. Капська, О. Киричук, М. Корнєв, А. Мудрик, Л. Савенкова та ін.); шляхи комунікативної підготовки майбутніх спеціалістів (А. Годлевська, О. Киричук, О. Коропецька, Р. Короткова, М. Коць, Т. Федотюк та ін.); психолого-педагогічні умови формування індивідуального стилю педагогічного спілкування (А. Коротаєв, В. Галузяк, Ю. Орлов, В. Петровський, К. Левін, М. Обозов, В. Мерлін, О. Мешко, О. Капітанець, Т. Тамбовцева, С. Шеін та ін.), культура педагогічного спілкування й комунікативна майстерність учителя (Л. Виготський, І. Зязюн, А. Макаренко, В. Сухомлинський, К. Ушинський та ін.).

Проблема формування культури педагогічного спілкування $\epsilon$ актуальною, оскільки саме від рівня розвитку комунікативних здібностей залежить становлення професійно-комунікативної компетентності майбутнього фахівця. Вища освіта вимагає не тільки пояснення студентові мовних фактів, явищ, процесів, розуміння та інтерпретацію отриманої інформації, а насамперед - вміння на практиці використовувати здобуті знання, тобто орієнтація робиться не на процес навчання, а на результат освітнього процесу - готовність випускника до подальшої професійнокомунікативної діяльності. Така підготовка потребує пошуку найбільш досконалих методичних шляхів організації навчально-виховного процесу.

Виходячи з актуальності досліджуваної проблеми, метою статті $€$ визначення ефективних умов та шляхів формування культури педагогічного спілкування в контексті компетентнісної парадигми професійно-комунікативної підготовки вчителів початкових класів.

На думку Н. Волкової, педагогічне спілкування - це «система соціально-психологічної взаємодії між учителем та учнем, спрямована на створення оптимальних соціально-психологічних умов для обопільної діяльності» [3, с. 435]. Н. Бутенко педагогічне спілкування розглядає як «взаємодію суб'єктів педагогічного процесу, здійснювану знаковими засобами і спрямовану на суттєві зміни властивостей, станів, поведінки й індивідуально-значеннєвих утворень партнерів» [2, с. 264]. Я. Кузьмінський розуміє педагогічне спілкування як «сукупність методів і засобів, застосування яких забезпечує досягнення мети навчання та виховання $\mathrm{i}$ визначає характер взаємодії між двома головними суб'єктами педагогічного процесу» [7, с. 142].

У контексті компетентнісного підходу поняття «культура педагогічного спілкування» розглядається як складова професійної компетентності педагога, що становить собою компетентність у спілкуванні, яка детермінується його особистісно комунікативним потенціалом, а також системою фахової комунікативної підготовки, спрямованою на формування таких професійних умінь та навичок, що 
забезпечують наявність перцептивної, інтерактивної та комунікативної компетенцій майбутнього педагога.

Культура педагогічного спілкування, високий рівень комунікативних здібностей педагога $є$ важливим показником готовності вчителя до педагогічної взаємодії 3 учнями: без певного рівня комунікативних здібностей неможливо говорити про готовність випускника педагогічного вузу до творчого вирішення професійних завдань.

На визначальну роль і велике значення педагогічного спілкування в навчально-виховному процесі вказували Н. Волкова, А. Годлевська, О. Киричук, Р. Короткова, В. Сухомлинський, Т. Федотюк та ін. Так, В. Сухомлинський підкреслював: «Кожне слово, що звучить у стінах школи, повинно бути продуманим, мудрим, цілеспрямованим й - це особливо важливо - зверненим до совісті живої конкретної людини, з якою ми маємо справу..., щоб не було знецінювання слів, а навпаки - щоб ціна слова постійно зростала» [8, с. 263].

Н. Дусь зауважує, слід ототожнювати поняття «компетенція в педагогічному спілкуванні» та «компетентність у педагогічному спілкуванні». Компетенція в педагогічному спілкуванні розглядається як «наявність у педагога знань технології педагогічного спілкування (суть, особливості, функції, структура), обізнаність у цій технології; усвідомлення необхідних для його здійснення комунікативних умінь та навичок» [4, с. 78]. Закладається вона системою відповідних навчальних дисциплін. А компетентність у педагогічному спілкуванні, відповідно, $\epsilon$ «свідченням готовності до здійснення педагогічного спілкування на високому професійному рівні, що, звісно, базується на основі компетенції особистості в педагогічному спілкуванні» [4, с. 79]. Формується вона, окрім системи відповідних навчальних дисциплін, і власним особистісним досвідом здійснення такого виду педагогічної діяльності.

Ми розглядаємо процес формування професійно-комунікативної компетентності майбутнього вчителя початкових класів як складний i багатобічний процес, як педагогічну систему, під якою ми, слідом за В. Беспалько, розуміємо «сукупність взаємопов'язаних засобів, методів i процесів, які необхідні для створення організованого, цілеспрямованого i навмисного педагогічного впливу на формування особистості» $[1$, с. 6]. Для виявлення компонентного складу даної системи та іï підсистем, їх зв’язку i відносин у процесі iii функціонування і розвитку, нами застосовувався системний підхід, основні положення якого представлені в працях Ю. Конаржевського, Н. Кузьміної, Г. Серікова, В. Сластьоніна та ін.).

Формування культури педагогічного спілкування майбутнього вчителя початкової школи передбачає вирішення таких завдань:

- освоєння діалогу як організаційного принципу комунікативної діяльності; 
- формування потреби в удосконаленні культури професійного спілкування;

- оволодіння етикою педагогічного спілкування;

- формування умінь використовувати вербальні та невербальні засоби педагогічного спілкування;

- оволодіння психологічною технікою переконуючого впливу в професійному спілкуванні педагога;

- освоєння умінь психотехніки;

- оволодіння технікою мовлення;

- розвиток умінь сприймати та розуміти інших людей;

- оволодіння атракцією в педагогічному спілкуванні;

- оволодіння методикою активного слухання в педагогічному спілкуванні.

Формування культури педагогічного спілкування майбутнього вчителя відбувається передусім у процесі вивчення лінгвістичних та педагогічних дисциплін: «Вступ до спеціальності», «Основи культури і техніки мовлення», «Психолого-педагогічне спілкування», «Педагогічна майстерність», «Педагогічні технології в початковій школі», «Основи етики та естетики», «Методика викладання української мови в початковій школі» та спецкурсів: «Основи екранного та сценічного мистецтва», «Педагогічна культура», «Психологічна культура» та ін.

На нашу думку, ефективними шляхами формування культури педагогічного спілкування майбутнього вчителя початкової школи є:

1) проведення лекційних, практичних занять $з$ питань діагностики та формування стильових особливостей професійного спілкування майбутнього педагога;

2) застосування в процесі вивчення спецкурсів рольових та ділових ігор, соціально-психологічних тренінгів, моделювання педагогічного спілкування, планування творчих завдань, словесних стимулюючих методів (бесіди, дискусії);

3) індивідуально-консультаційна робота;

4) читання й обговорення наукової та науково-популярної літератури 3 проблем професійного спілкування;

5) відвідування студентами наукових гуртків та проблемних груп;

6) участь студентів у наукових та науково-практичних конференціях;

7) написання студентами курсових, кваліфікаційних та магістерських робіт;

8) захист творчих проектів 3 проблем формування культури педагогічного культури майбутнього вчителя початкової школи;

9) проходження різноманітних видів педагогічної практики (навчальної, виробничої, літної педагогічної в оздоровчих таборах). 
I. Черезова підкреслює, що «мовленнєві уміння майбутніх учителів це феномен, розвиток якого зумовлюється сукупністю психофізіологічних, соціокультурних i педагогічних чинників, сформованими знаннями студента про мовленнєву культуру і можливості їі застосування відповідно до потреби, особливостей та мети педагогічного процесу» [9, с. 14]. При цьому готовність до мовленнєвої діяльності розглядається як прояв спеціальних знань, мовленнєвої компетентності та мовленнєвого професіоналізму. На нашу думку, увага викладачів повинна зосередитися на таких аспектах:

1) формування нормативної вимови студентів і подолання діалектних впливів;

2) збагачення, уточнення й активізація лексичного запасу майбутніх учителів початкових класів;

3) глибоке оволодіння граматичними нормами мови і вдосконалення граматичного ладу мовлення студентів;

4) теоретичне i практичне засвоєння найважливіших текстологічних понять, що виступає узагальнюючо-підсумковим етапом роботи над розвитком мовлення майбутніх учителів-класоводів;

5) максимальний розвиток пізнавальної активності студентів, їхньої здатності до творчості, створення власних текстів, словесному відображення ситуацій, що вимагають опису, розповіді, роздуму.

Ефективність педагогічного спілкування значною мірою залежить від психологічних особливостей особистості вчителя, використовуваних ним засобів педагогічного впливу. Удосконалення i розвиток їх має охоплювати комунікативну, перцептивну, інтерактивну складові спілкування, які тісно пов’язані з пізнавальною, емоційною, мотиваційнорольовою сферами психіки. Тому оптимізація спілкування означає i вдосконалення психічного функціонування особистості вчителя.

Педагогічне спілкування є особливим видом творчості, адже кожне навчальне заняття - це ланцюг мікроскопічних педагогічних ситуацій. I кожна ситуація вимагає миттєвого обмірковування, швидкого й точного вирішення проблеми. На думку В. Кащенко, творчий підхід педагога до спілкування реалізується в умінні передавати інформацію, точно орієнтуючи іiі на співрозмовника, використовуючи при цьому всі засоби емоційного впливу - яскраву виразну мову, жести, міміку, гумор; умінні зрозуміти ситуацію й швидко прийняти потрібне рішення; умінні організувати взаємини зі студентами; умінні через спілкування виховувати особистість; умінні регулювати власні психічні стани, бути життєрадісним й оптимістичним у пошуку нових шляхів роботи [5, с. 115].

У комунікативному відношенні формується вміння організовувати на роботу, створити позитивний емоційний настрой, налагодити зворотний зв’язок зі студентами. Важливими вміннями творчого педагога є: чітке планування роботи на заняттях, дотримання оптимального дозування часу, 
організація спільного проблемного пошуку рішення поставлених завдань. Викладач - це не лише предметодавець, а цікава, різнобічно розвинута особистість. Завдяки ньому створюються певні умови для розвитку творчих здібностей кожного студента. Завжди актуальними є творчі й оригінальні підходи до вибору форм, методів і прийомів навчання та виховання. Вважаємо за доцільне виділити основні етапи технології формування культури педагогічного спілкування майбутнього вчителя початкових класів:

1. Здійснення діагностики культури педагогічного спілкування майбутнього педагога.

2. Формування теоретичної бази студента педагогічного навчального закладу з проблем професійно-педагогічної культури.

3. Створення програми саморозвитку основних компонентів педагогічного спілкування.

4. Виконання вправ, ігор із формування культури педагогічного спілкування майбутнього вчителя початкової школи.

5. Самоконтроль та самодіагностика набутих професійнокультурних якостей протягом педагогічних практик.

На наш погляд, основними методами формування культури педагогічного спілкування майбутнього вчителя початкової школи є: научіння (освоєння предметної інформації); навчання в діяльності (безпосереднє включення студентів у процес реальної професійної діяльності); ділові та рольові ігри (особливий вид антропотехніки, що передбачає оволодіння різними компонентами професійної майстерності в ситуації, яка містить елементи умовності); консультування; тренінги спілкування; виконання індивідуальних завдань.

Викладач, який працює над розвитком культури педагогічного спілкування майбутнього вчителя початкової школи, повинен мати перед собою перспективу, певну концепцію, яка допомагає орієнтуватися в потоці видань, що становлять науково-методичний супровід педагогічних, лінгвістичних дисциплін у системі підготовки майбутніх вчителів початкових класів. Орієнтиром при цьому має бути забезпечення органічного взаємозв'язку розвитку мовлення, формування педагогічного спілкування i професійного становлення вчителя початкових класів, у професіограмі якого особлива роль належить всебічному розвитку культури спілкування.

Отже, формування культури педагогічного спілкування $є$ одним із важливих напрямів професійної підготовки сучасного вчителя початкових класів, фахівця високої кваліфікації, майбутнього вченого, педагога, психолога. Комунікативні вміння майбутнього вчителя початкової школи становлять сформовані на основі засвоєних знань, навичок і практичного досвіду способи і прийоми спілкування, спрямовані на реалізацію комунікативної функції педагогічної діяльності. Ефективність формування культури педагогічного спілкування в майбутніх учителів 
початкової школи залежить від створення у процесі їхньої професійної підготовки таких педагогічних умов: стимулювання розвитку мотивів комунікативної діяльності, формування у студентів чітких уявлень про сутність і структуру комунікативних умінь, організації діалогічної взаємодії суб’єктів навчального процесу.

\section{Література}

1. Беспалько В.П. Системно-методическое обеспечение учебно-воспитательного процесса подготовки специалистов / В. П. Безпалько, Ю. Г. Татур. - М.: Высш. шк., 1989. - 144 с.

2. Бутенко Н. Ю. Комунікативні процеси у навчанні : [підручник] / Н. Ю. Бутенко - К. : КНЕУ, 2004. $-382 \mathrm{c}$.

3. Волкова Н. П. Педагогіка : [навч. посіб.] / Наталія Павлівна Волкова. - К. : Вид. центр «Академія», 2001. - 576 с.

4. Дусь Н. А. Модель формування культури педагогічного спілкування в майбутніх учителів початкових класів / Н. А. Дусь // Професійна підготовка педагогічних кадрів в умовах інноваційної перебудови української національної освіти : сучасний стан, проблеми, перспективи розвитку : матеріали Міжвузівської науково-практичної конференції. - Хмельницький : ХГПА, 2007. - С.77-82.

5. Кащенко В. Л. Педагогическая коррекция: исправление недостатков характера у детей и подростков : [книга для учителя] / В. Л. Кащенко. - [2-е изд.]. - М. : Просвещение, 1994. - 345 с.

6. Кузьмина Н. В. Педагогическое мастерство учителя как фактор развития способностей учащихся / Н. В. Кузьмина // Вопросы психологии. - 1984. - № 1. - С. 20-27.

7. Кузьмінський А. І. Педагогіка вищої школи : [навч. посібник] / Анатолій Іванович Кузьмінський. - К. : Знання, 2005.- $486 \mathrm{c}$.

8. Сухомлинський В. О. Вибрані твори : у 5-и т. / Василь Олександрович Сухомлинський. - К. : Рад. шк., 1976. - Т.1. -654 с.

9. Черезова І. О. Мовленнєва компетентність як одна з головних вимог до індивідуальнопсихологічних особливостей сучасного вчителя / І. О. Черезова // Психологія. - 2005. - № 2. - С.11-16.

Стаття надійшла до редакції 18.11.2011 p. 